\title{
Is seaweed extract an elicitor compound? Changing proline content in drought-stressed bean plants
}

\author{
Marcia Eugenia Amaral Carvalho, Paulo Roberto de Camargo e Castro, \\ Salete Aparecida Gaziola, Ricardo Antunes Azevedo*
}

\begin{abstract}
Abiotic stresses negatively affect crop development and yield. However, the use of seaweed extracts can alleviate production losses through improvement of the antioxidant system and synthesis of compatible osmolytes. The aim of this study was to assess the effects of Ascophyllum nodosum extract on antioxidant response and yield of common bean plants (Phaseolus vulgaris) under drought stress. Therefore, two methods of application (foliar spray and soil irrigation) and two doses (5 and $10 \mathrm{~mL} \mathrm{~L}^{-1}$ ) were tested, whereas untreated plants were used as control. There were no significant differences in malondialdehyde and hydrogen peroxide contents among treatments, indicating that application of seaweed extract did not change the oxidative status in treated plants when compared to the control ones. On the other hand, the use of seaweed extract increased proline content even prior to drought stress (46.3 to 145.4\% when compared to the control), and this increment remained until the $10^{\text {th }}$ day of stress (from 60.1 to $201.7 \%$ over the reference plants), supporting early evidences that $A$. nodosum extract is a plant elicitor. The yield parameters were not affected by the extract, probably due to the severe drought stress which plants were submitted. The results suggest that $A$. nodosum extract affects proline metabolism in Phaseolus vulgaris plants, making the synthesis of this osmolyte more responsive to drought stress because seaweed-treated plants presented a higher proline content than the control ones during the exposure to water deficit.
\end{abstract}

Keywords: Ascophyllum nodosum, compatible osmolyte, Phaseolus vulgaris

Due to the fast global environmental changes, the ability to maintain or even increase crop quality and yield is becoming difficult. Abiotic stresses cause morphological, physiological, biochemical, and molecular changes that adversely affect plant development and productivity. Drought generates an insufficient water supply to plants resulting in oxidative stress, yield losses and plant death (Zhang \& Ervin, 2008; Cia et al., 2012; Boaretto et al., 2014; Medici et al., 2014; Mansori et al., 2015). However, crop performance can be improved with the use of seaweed extracts, which are an environmentally friendly alternative to the use of fertilizers and biostimulants (Craigie, 2011; Carvalho \& Castro,
2014; Artioli et al., 2015; Battacharyya et al., 2015). Ascophyllum nodosum (L.) Le Jolis extract contains several compounds (such as auxins, cytokinins and gibberellin) which can stimulate plant development and yield, also improving tolerance to abiotic stresses (Rayorath et al., 2008a,b; Craigie, 2011; Khan et al., 2011; Kumar \& Sahoo, 2011; Nair et al., 2012; Carvalho et al., 2013, 2014; Carvalho \& Castro, 2014; Artioli et al., 2015; Battacharyya et al., 2015). However, the action mechanisms of $A$. nodosum extract are little understood and their elucidation is important for the development of strategies that increase plant yield and tolerance to abiotic stresses.

There are few studies that associate the

Received: 25 March 2017 Accepted: 26 February 2018 
effects of seaweed extracts on plant development and antioxidant system of important tropical crops under drought stress, and none of them reported the influence of this biostimulant on fruit/grain yield and quality. For instance, Mansori et al. (2015) showed that seaweed-treated bean plants exhibited increases in superoxide dismutase (SOD, EC 1.15.1.1), catalase (CAT, EC 1.11.1.6) and ascorbate peroxidase (APX, EC 1.11.1.11) activity during drought stress when compared to the control plants. Spann \& Little (2011) reported that application of seaweed extract, as foliar spray and soil drench, increased the drought tolerance of citrus stock plants under water deficit, however, there is no information about either productivity or oxidative stress indicators.

In this work, the common bean (Phaseolus vulgaris L.) was selected as the plant subject because it is a relevant economically crop for developing countries, in which it is often used to mitigate hunger and malnutrition. This study aimed to evaluate the effects of doses and application methods of $A$. nodosum extract on biochemical and yield parameters of common bean plants under drought stress. The experiment was carried out in a greenhouse without temperature and humidity control, from November 2011 to January 2012, in Piracicaba, São Paulo state,

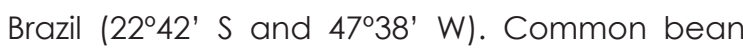
seeds ( $P$. vulgaris CV. IAC-Alvorada) were placed in plastic containers $\left(15 \mathrm{dm}^{3}\right)$ which were filled with a mixture of clay, silt and sand (2:1:1). The soil composition and properties are listed in the Supplementary Table 1.

The treatments were: i) control (water), ii) foliar spray with seaweed extract $5 \mathrm{~mL} \mathrm{~L}^{-1}$, iii) foliar spray with seaweed extract $10 \mathrm{~mL} \mathrm{~L}^{-1}$, iv) soil irrigation with seaweed extract $5 \mathrm{~mL} \mathrm{~L}^{-1}$, and v) soil irrigation with seaweed extract $10 \mathrm{~mL}$ $\mathrm{L}^{-1}$. The physical and chemical characteristics of $A$. nodosum liquid extract are presented in the Supplementary Table 2. Applications were performed on the $14^{\text {th }}, 28^{\text {th }}$ and $35^{\text {th }}$ days after sowing (when plants were at vegetative stage), in the morning (from 8:30 am to 9:30 am).

The drought stress was initiated by suppressing irrigation when plants were at R5 stage, i.e. When $50 \%$ or more of them exhibited the onset of flowering (CIAT, 1986). The moisture content was determined by drying soil samples at $105^{\circ} \mathrm{C}$ until constant weight; it was 15.0, 7.0 and $6.0 \%$ on 0,5 and 10 days of drought stress, respectively. After 10 days of drought stress, plants were re-irrigated and the experiment was carried out until the end of the common bean plants biological cycle. During this period, plants received three more applications of seaweed extract $\left(56^{\text {th }}, 63^{\text {rd }}\right.$ and $70^{\text {th }}$ days after sowing) in the morning (from 8:30 am to 9:30 am).

During drought stress $(0,5$ and 10 days of irrigation suppression), fully expanded leaves from the middle third of the plants were collected (from 8:30 am to 9:00 am), to perform the biochemical analysis. Lipid peroxidation was measured as malondialdehyde production as described by Heath \& Packer (1968). Hydrogen peroxide $\left(\mathrm{H}_{2} \mathrm{O}_{2}\right)$ content was determined according to Alexieva et al. (2001). The extraction and determination of proline content was performed as described by Bates et al. (1973). Enzyme extraction and evaluation of CAT activity was carried out according to Azevedo et al. (1998), and protein content of samples was determined by the Bradford's method (1976).

At harvest, the number of pods was assessed, and then they were placed in paper bags and taken to an oven for $72 \mathrm{~h}$ at $60{ }^{\circ} \mathrm{C}$. Subsequently, the dry mass and number of grains, 20-grain dry mass and number of grains per pod were determined. The experimental design was completely randomized, with five treatments, eight replications for production parameters and four replications to perform biochemical analysis. The obtained data were submitted to analysis of variance (ANOVA) at $5 \%$ significance level, and Tukey's test ( $a \leq 0.05$ ) was used to compare means among treatments. Data from proline content and CAT activity, which were collected on days 0 and 5 of drought stress, were transformed to $\log _{10}(x)$ to be in accordance with statistical assumptions to perform the ANOVA. After analysis, data were converted to the original scale, to facilitate comparison of results among treatments. All statistical analyses were performed using SAS ${ }^{\circledR}$ statistical software (SAS Institute, 2011). 
Seaweed extract produced from A. nodosum is able to stimulate plant development and yield, through improvement of tolerance mechanisms to abiotic stresses (Zhang \& Ervin, 2008; Craigie, 2011; Nair et al., 2012; Mansori et al., 2015; Artioli et al., 2015; Battacharyya et al., 2015). However, lipid peroxidation (indicated as malondialdehyde content) and hydrogen peroxide concentration did not differ among treatments (Figure 1A-B).
A

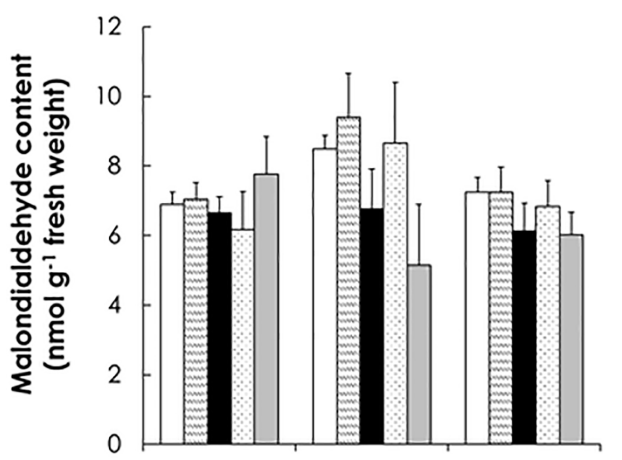

C

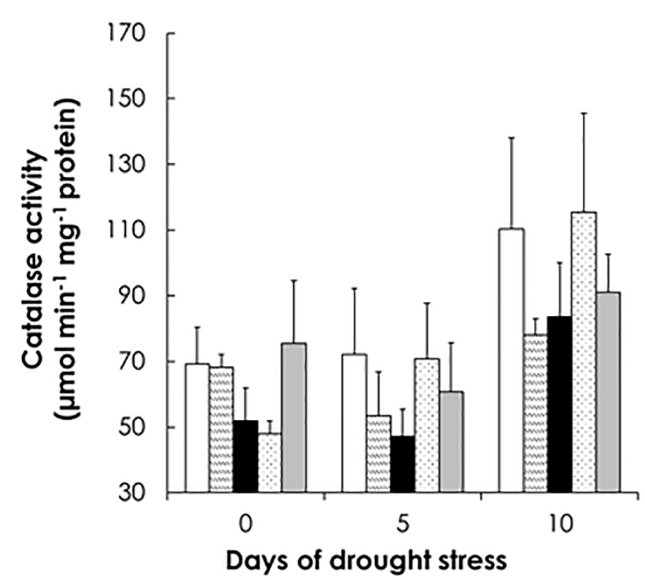

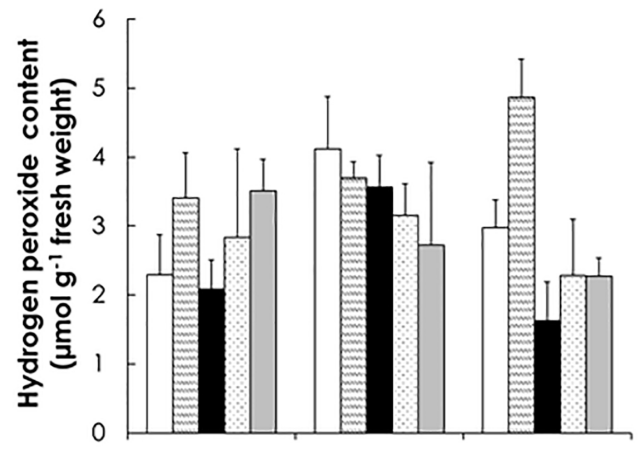

D

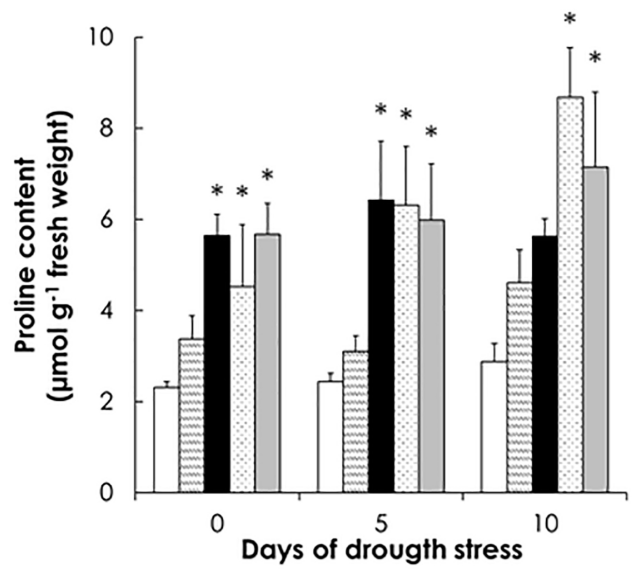

Figure 1. Effects of doses and application methods of Ascophyllum nodosum extract on malondialdehyde (A) and hydrogen peroxide contents (B), CAT activity (C) and proline content (D) in common bean (Phaseolus vulgaris) plants on 0,5 and 10 days of drought stress. FS 5: foliar spray $5 \mathrm{~mL} \mathrm{~L}^{-1} ; \mathrm{FS} \mathrm{10:} \mathrm{foliar} \mathrm{spray} 10 \mathrm{~mL} \mathrm{~L}^{-1}$; SI 5: soil irrigation $5 \mathrm{~mL} \mathrm{~L}^{-1}$ and SI 10: soil irrigation $10 \mathrm{~mL} \mathrm{~L}^{-1}$. Values are mean \pm standard error $(\mathrm{n}=4) .{ }^{*}$ indicates differences between the treatment and control by Tukey's test $(a \geq 0.05)$ on each day of evaluation.

On the other hand, the use of $A$. nodosum extract decreased lipid peroxidation in creeping bentgrass (Agrostis stolonifera L.) subjected to heat stress for 42 days (from 24 to $52 \%$, when compared to the control) (Zhang \& Ervin, 2008). According to these authors, seaweed extract improved plant tolerance because it is able to increase the endogenous cytokinin content. Currently, it is known that $A$. nodosum extract changes the cytokinin synthesis in Arabidopsis thaliana L. by regulating expression of genes related to the metabolism of this hormone (Khan et al., 2011).

In order to prevent or reduce the damage caused by the production of reactive oxygen species (such as hydrogen peroxide) due to abiotic stresses, a complex detoxification mechanism that involve the enzymatic systems is triggered in plants (Ashraf \& Foolad, 2007; Zhang \& Ervin, 2008; Cia et al., 2012; Nair et al., 2012; Boaretto et al., 2014; Gratão et al., 2015; Mansori et al., 2015). Hydrogen peroxide may be detoxified by CAT, which is one of key enzymes that scavenge this compound (Azevedo et al., 1998; Boaretto et al., 2014; Mansori et al., 2015). However, CAT activity did not exhibit any major significant variation among treated and control plants (Figure 1C), and, hence, the role of other 
peroxidases that were not evaluated cannot be ruled out.

Previous studies also reported changes in the antioxidant compounds related to the non-enzymatic mechanisms, such as carotenoid, ascorbic acid and total phenolic contents, on seaweed-treated plants (Zhang \& Ervin, 2008; Carvalho et al., 2014; Mansori et al., 2015; Kasim et al., 2015). In the present work, we noticed that application of algae extract triggered increases in the proline content in common bean plants under drought stress (Figure 1D). Even on day 0 , there was an increment that ranged from 46.3 to $145.4 \%$ when compared to the control, evidencing that proline accumulation is further induced prior to drought stress. Furthermore, untreated plants exhibited little variation in the proline content during the period of stress. These responses indicate that $A$. nodosum extract is an elicitor compound that influence proline metabolism, making it even more responsive in plants subjected to drought stress because treated-plants exhibited a higher proline production than the control ones during the water-deficit period (from 27.5 to $201.7 \%$ ).

According to Ashraf \& Foolad (2007), proline production is induced by several stresses, acting in osmotic adjustment, stabilization of sub-cellular structures, free radicals scavenging, redox potential buffering and induction of stressresponsive genes. Its concentration depends on the species, cultivars, plant organs and phenological stage, also varying according to the type of abiotic stress and its severity (Claussen, 2005; Ashraf \& Foolad, 2007; Mafakheri et al., 2010; Kavi Kishor \& Sreenivasulu, 2014). In common bean, proline production via upregulation of P5CS was differently affected by drought, salt and cold (Chen et al., 2009): both gene expression peak and proline synthesis were delayed by the plant exposure to the drought condition, when compared to the other stresses (days vs hours). However, drought-stressed plants exhibited the highest proline accumulation, reaching approximately $2.60 \mu \mathrm{mol}$ against 0.44 $\mu \mathrm{mol} \mathrm{g} \mathrm{g}^{-1} \mathrm{FW}$ in those under cold and salt stresses (Chen et al., 2009).

In Arabidopsis, the removal of feedback inhibition of an enzyme from the proline metabolism resulted in a high accumulation of this osmolyte $\left(52 \mathrm{mmol} \mathrm{g}^{-1} \mathrm{FW}\right.$, approximately $300 \%$ when compared to the control), which provided increases in the plant tolerance to osmotic stresses (Hong et al., 2000). Curiously, the application of $A$. nodosum extract enhanced the proline synthesis (up to 52.52\%) in Arabdopsis under freezing stress (Nair et al., 2012). These authors showed that lipophilic components of $A$. nodosum extract changes proline concentration by regulating expression of genes related to its biosynthesis and degradation (P5CS1, P5CS2 and ProDH, respectively). Although proline accumulation does not always occur in plants under abiotic stresses, there is a strong correlation between stress tolerance and osmolyte accumulation in higher plants (Hong et al., 2000; Ashraf \& Foolad, 2007; Kavi Kishor \& Sreenivasulu, 2014). Therefore, it is expected that plants overproducing proline are more tolerant to drought stress, which may result in higher yield when compared to the control or maintenance of standard yield, even under stress. However, yield components did not show statistical differences among treatments (Table 1).

Probably, some of the results were due to the severe drought stress by which the plants were subjected ( 10 days), since we observed that plants showed a high number of aborted flowers

Table 1. Effects of doses and application methods of Ascophyllum nodosum extract on yield components of bean (Phaseolus vulgaris) plants subjected to drought stress for 10 days.

\begin{tabular}{|c|c|c|c|c|c|}
\hline Treatments & $\begin{array}{l}\text { Number } \\
\text { of pods }\end{array}$ & $\begin{array}{l}\text { Number } \\
\text { of grains }{ }^{n s}\end{array}$ & $\begin{array}{l}\text { Grains } \\
\text { per pod }^{\text {ns }}\end{array}$ & $\begin{array}{l}\text { Dry mass } \\
\text { of grains }{ }^{\text {ns }}\end{array}$ & $\begin{array}{l}\text { 20-grain } \\
\text { dry mass }\end{array}$ \\
\hline Control & $9.87 \pm 2.68$ & $26.50 \pm 7.50$ & $2.71 \pm 0.26$ & $5.17 \pm 1.70$ & $3.89 \pm 0.31$ \\
\hline Foliar spray $5 \mathrm{~mL} \mathrm{L-1}$ & $9.75 \pm 1.58$ & $29.25 \pm 4.64$ & $2.77 \pm 0.18$ & $6.67 \pm 1.18$ & $4.55 \pm 0.18$ \\
\hline Foliar spray $10 \mathrm{~mL} \mathrm{~L}^{-1}$ & $13.25 \pm 2.84$ & $40.63 \pm 10.02$ & $3.09 \pm 0.28$ & $9.72 \pm 2.67$ & $4.78 \pm 0.34$ \\
\hline Soil irrigation $5 \mathrm{~mL} \mathrm{~L}{ }^{-1}$ & $12.75 \pm 3.64$ & $31.75 \pm 8.67$ & $2.58 \pm 0.19$ & $6.88 \pm 2.03$ & $4.33 \pm 0.25$ \\
\hline Soil irrigation $10 \mathrm{~mL} \mathrm{~L}^{-1}$ & $8.12 \pm 2.09$ & $21.88 \pm 6.16$ & $2.60 \pm 0.25$ & $4.76 \pm 1.49$ & $4.35 \pm 0.18$ \\
\hline$p$-value & 0.6188 & 0.5118 & 0.5493 & 0.3842 & 0.1494 \\
\hline
\end{tabular}


and pods, and less developed grains than the usual (smaller size and fewer seeds per pod). We can conclude that application of $A$. nodosum extract, as soil drench with solution containing 5 and $10 \mathrm{~mL} \mathrm{~L}^{-1}$, induces proline synthesis (from 95.7 to $201.7 \%$ ) in common bean cV. IAC-Alvorada prior and during drought stress, indicating that $A$. nodosum extract affects the proline metabolism through an elicitor mechanism.

\section{References}

Alexieva, V., Sergiev, I., Mapelli, S., Karanov, E. 2001. The effect of drought and ultraviolet radiation on growth and stress markers in pea and wheat. Plant, Cell and Environment 24: 13371344.

Arioli, T., Mattner, S.W., Winberg, P.C. 2015 Applications of seaweed extracts in Australian agriculture: past, present and future. Journal of Applied Phycology 27: 2007-2015.

Ashraf, M., Foolad M.R. 2007. Roles of glycine betaine and proline in improving plant abiotic stress resistance. Environmental and Experimental Botany 59: 206-216.

Azevedo, R.A., Alas, R.M., Smith, R.J., Lea, P.J. 1998. Response of antioxidant enzymes to transfer from elevated carbon dioxide to air and ozone fumigation, in the leaves and roots of wildtype and a catalase-deficient mutant of barley. Physiologia Plantarum 104: 280-292.

Bates, L.S., Waldren, R.P., Teare, I.D. 1973. Rapid determination of free proline for water-stress studies. Plant and Soil 39: 205-207.

Battacharyya, D., Babgohari, M.Z., Rathor, P., Prithiviraj, B. 2015. Seaweed extracts as biostimulants in horticulture. Scientia Horticulturae 196: 39-48.

Boaretto, L.F., Carvalho, G., Borgo, L., Creste, S., Landell, M.G., Mazzafera, P., Azevedo, R.A. 2014. Water stress reveals differential antioxidant responses of tolerant and non-tolerant sugarcane genotypes. Plant, Physiology and Biochemistry 74: 165-175.

Bradford, M.M. 1976. Rapid and sensitive method for quantification of microgram quantities of protein utilizing the principle of protein-dye binding. Analytical Biochemistry 72: 248-254.

Carvalho, M.E.A., Castro, P.R.C. 2014. Extratos de algas e suas aplicações na agricultura. Piracicaba: ESALQ - DIBD.

Carvalho, M.E.A., Castro, P.R.C., Gallo, L.A., Ferraz Junior, M.V.C. 2014. Seaweed extract provides development and production of wheat.
Agrarian 7: 166-170.

Carvalho, M.E.A., Castro, P.R.C., Novembre, A.D.C., Chamma, H.M.C.P. 2013. Seaweed extract improves the vigor and provides the rapid emergence of dry bean seeds. AmericanEurasian Journal of Agricultural \& Environmental Sciences 13: $1104-1107$.

Chen, J-B., Wang, S-M., Jing, R-L., Mao, X-G. 2009. Cloning the PvP5CS gene from common bean (Phaseolus vulgaris) and its expression patterns under abiotic stresses. Journal of Plant Physiology, 166: 12-19.

Cia, M.C., Guimarães, A.C.R., Medici, L.O., Chabregas, S.M., Azevedo, R.A. 2012. Antioxidant response to water deficit by drought-tolerant and -sensitive sugarcane varieties. Annals of Applied Biology 161: 313-324

CIAT (Centro Internacional de Agricultura Trpoical). 1986. Etapas de desarrollo de la planta de frijol común (Phaseolus vulgaris L.). Cali: CIAT. $34 \mathrm{p}$.

Claussen, W. 2005. Proline as a measure of stress in tomato plants. Plant Science, 168: 241-248.

Craigie, J.S. 2011. Seaweed extract stimuli in plant science and agriculture. Journal of Applied Phycology 23: 371-393.

Gratão, P.L., Monteiro, C.C. Tezotto, T., Carvalho, R.F., Alves, L.R., Peters, L.P., Azevedo, R.A. 2015. Cadmium stress antioxidant responses and rootto-shoot communication in grafted tomato plants. Biometals 28: 803-816.

Heath, R.L., Packer, L. 1968. Photoperoxidation in isolated chloroplasts: I. Kinetics and stoichiometry of fatty acid peroxidation. Archives in Biochemistry and Biophysics, 125: 189-198.

Hong, Z., Lakkineni, K., Zhang, Z., Verma, D.P.S. 2000. Removal of feedback inhibition of $d$ 1-pyrroline-5-carboxylate synthetase results in increased proline accumulation and protection of plants from osmotic stress. Plant Physiology, 122: 1129-1136.

Kasim, W.A., Hamada, E.A.M., El-Din, N.G.S., Eskander, S.K. 2015. Influence of seaweed extracts on the growth, some metabolic activities and yield of wheat grown under drought stress. International Journal of Agronomy and Agricultural Research, 7: 173-189.

Kavi Kishor, P.B., Sreenivasulu, N. 2014. Is proline accumulation per se correlated with stress tolerance or is proline homeostasisa more critical issue? Plant, Cell and Environment, 37: 300-31 1.

Khan, W., Hiltz, D., Critchley, A.T., Prithiviraj, B. 2011. Bioassay to detect Ascophyllum 
nodosum extract-induced cytokinin-like activity in Arabidopsis thaliana. Journal of Applied Phycology 23: 409-414.

Kumar, G., Sahoo, D. 2011. Effect of seaweed liquid extract on growth and yield of Triticum aestivum var. Pusa Gold. Journal of Applied Phycology 23: 251-255.

Mafakher, A., Siosemardeh, A., Bahramnejad, B., Struik, P.C., Sohrabi, Y. 2010. Effect of drought stress on yield, proline and chlo rophyll contents in three chickpea cultivars. Australian Journal of Crop Science, 4: 580-585.

Mansori, M., Chernane, H., Latique, S., Benaliat, A., Hsissou, D., Kaova, M.E. 2015. Seaweed extract effect on water deficit and antioxidative mechanisms in bean plants (Phaseolus vulgaris L.). Journal of Applied Phycology 20: 1689-1698.

Medici, L.O., Reinert, F., Carvalho, D.F., Kozak, M, Azevedo, R.A. 2014. What about keeping plants well watered? Environmental and Experimental Botany 99: 38-42

Nair, P., Kandasamy, S., Zhang, J., Ji, X., Kirby, C., Benkel, B., Hodges, M.D., Critchley, A.T., Hiltz, D., Prithiviraj, B. 2012. Transcriptional and metabolomic analysis of Ascophyllum nodosum mediated freezing tolerance in Arabidopsis thaliana. BMC Genetics 13: 643.

Rayorath, P., Jithesh, M.N, Farid, A., Khan, W., Palanisamy, R., Hankins, S.D., Critchley, A.T., Prithiviraj, B. 2008b. Rapid bioassays to evaluate the plant growth promoting activity of Ascophyllum nodosum (L.) Le Jol. using a model plant, Arabidopsis thaliana (L.) Heynh. Journal of Applied Phycology 20: 423-429.

Rayorath, P., Khan, W., Palanisamy, R., Mackinnon, S.L., Stefanova, R., Hankins, S.D., Critchley, A.T., Prithiviraj, B. 2008a. Extracts of the brown seaweed Ascophyllum nodosum induce gibberellic acid (GA3)-independent amylase activity in barley. Journal of Plant Growth Regulation 27: 370-379.

SAS Institute. 2011 . SAS/STAT User's Guide: Version 9.3. Cary: SAS Institute.

Spann, T.M., Little, H.A. 2011. Applications of a commercial extract of the brown seaweed Ascophyllum nodosum increases drought tolerance in container-grown 'Hamlin' sweet orange nursery trees. HortScience, 46: 577-582.

Zhang, X., Ervin, E.H. 2008. Impact of seawesed extract-based cytokinins and zeatin riboside on creeping bentgrass heat tolerance. Crop Science 48: 364-370. 